\title{
Posner versus Kelsen : the challenges for scientific analysis of law
}

\section{Malecka, Magdalena}

2017-06

Malecka, M 2017 , ' Posner versus Kelsen : the challenges for scientific analysis of law ' ,

European Journal of Law and Economics, vol. 43 , no. 3 , pp. 495-516 . https://doi.org/10.1007/s10657-016-9552-1

http://hdl.handle.net/10138/308708

https://doi.org/10.1007/s10657-016-9552-1

acceptedVersion

Downloaded from Helda, University of Helsinki institutional repository.

This is an electronic reprint of the original article.

This reprint may differ from the original in pagination and typographic detail.

Please cite the original version. 


\title{
Posner versus Kelsen: The challenges for scientific analysis of law
}

\author{
Magdalena Małecka \\ University of Helsinki
}

\begin{abstract}
Law \& economics scholars claim, among other things, to provide explanations of how law impacts behaviour. The aim of this article is to shed light on the conceptual and methodological difficulties related to analysis of the impact that law has on behaviour. The analysis advanced in the paper takes as its starting point a commentary on Richard Posner's interpretation of Hans Kelsen's pure theory of law. The work of Kelsen is treated as a metatheoretical analysis that reveals some of the presumptions of theoretical approaches to law that claim to be scientific and, in particular, that claim to scientifically analyse the law's influence on behaviour. The article concludes with a methodological proposal on how to approach the identified methodological challenges and conceptual tensions that law \& economics contends with.
\end{abstract}

A final version of this article has been published as: Małecka M., 2017, Kelsen vs. Posner. The challenges for scientific analysis of law, European Journal of Law and Economics: 495-516 and is available at Springer via DOI 10.1007/s10657-016-9552-1.

Key-words 























